\title{
Deep-seated gravitational slope deformations as possible suitable locations for prehistoric human settlements: An example from the Italian Western Alps
}

\author{
Maria Gabriella Forno ${ }^{\mathrm{a}, \mathrm{b}, *}$, Marco Gattiglio ${ }^{\mathrm{a}}$, Franco Gianotti ${ }^{\mathrm{a}}$, Antonio Guerreschi ${ }^{\mathrm{c}}$, \\ Luca Raiteri ${ }^{\mathrm{d}}$ \\ ${ }^{a}$ Dipartimento di Scienze della Terra, University of Torino, Via Valperga Caluso 35, 10125 Torino, Italy \\ ${ }^{\mathrm{b}}$ NatRisk Interdipartimental Centre, University of Torino, Via Leonardo da Vinci 44, 0095 Grugliasco, Italy \\ ${ }^{\mathrm{c}}$ Dipartimento di Biologia ed Evoluzione, University of Ferrara, Corso Ercole I d'Este 32, 44100 Ferrara, Italy \\ ${ }^{\mathrm{d}}$ Regione Autonoma Valle d'Aosta, Soprintendenza per i beni e le attività culturali, Piazza Roncas 12, 11100 Aosta, Italy
}

\section{A R T I C L E I N F O}

\section{Article history:}

Available online 28 March 2013

\begin{abstract}
A B S T R A C T
The Plan di Modzon is a mountain area $(2300 \mathrm{~m})$ located in the Verrogne Valley, NW of Aosta (Western Alps). It occurs along the contact between the Middle Penninic (micaschist and gneiss from the Gran San Bernardo Nappe) and the overlying upper units of the Piedmont Zone (carbonate calcschist alternating with marble).

This area, largely shaped by Pleistocene glaciers, was involved in a wide deep-seated gravitational slope deformation (Pointe Leysser DSGSD) on the western extension of the Becca France doubled ridges. Several ridges that were affected by glacial erosion, discontinuously covered by glacial sediments, are present throughout the area. Extremely fractured rocks and various gravitational forms (minor scarps and trenches) mark the DSGSD.

Several archaeological sites (MF1-MF9) have recently been found between 2242 and $2292 \mathrm{~m}$ asl. They have revealed artifacts of rock crystal (hyaline quartz) referred to the Sauveterrian stage of the Mesolithic. An ensemble of other archaeological evidence is referred to the Copper Age. The investigation in progress specifically concerns the systematic excavation of sites MF1 and MF3.

Some concomitant morphological factors have created very favorable conditions for prehistoric settlements in the Plan di Modzon area, including the exceptionally wide valley floor directly perched on the main Dora Baltea Valley, in consequence of the Verrogne Glacier diversion promoted by the P. Leysser DSGSD. Easy and direct accessibility to this area is provided by the gently-dipping slope of the Dora Baltea Valley affected by the DSGSD. The ridged and grooved morphology as the result of the glacial and gravitational interaction, offered wide surfaces free from geological hazards (debris flow and avalanche processes). The DSGSD is, therefore, one of the primary causes of the archaeological settlement of this area, contributing to create a morphology adapted to prehistoric settlements.
\end{abstract}

(c) 2013 Elsevier Ltd and INQUA. All rights reserved.

\section{Introduction}

Over the last few years, several archaeological remains have been found in the Plan di Modzon area, on the southern slope of Mont Fallère in the middle Aosta Valley, in which the Dora Baltea River flows (Figs. 1 and 2). The Mont Fallère archaeological settlements (MF1-MF9) were discovered at a high altitude

\footnotetext{
* Corresponding author. Department of Scienze delle Terra, University of Turin, Via Valperga Caluso 35, 10100 Turin, Italy.

E-mail address: gabriella.forno@unito.it (M.G. Forno).
}

(approximately $2250 \mathrm{~m}$ ): in August 1998 (MF1 and MF2) and 2008-2011 (MF3-MF9). They have been initially investigated with preliminary archaeological excavations and surface collections. Subsequent research has continued since 2008 with a series of surveys (2008 and 2010), archaeological excavation campaigns (three campaigns at MF1 and one at MF3) (Mezzena and Perrini, 1999, 2002; Guerreschi et al., 2010) and a geological survey (Raiteri et al., 2008).

At the same time, geological research has been conducted in the adjacent Becca France ridge, which was involved in a wide deepseated gravitational slope deformation (Pointe Leysser DSGSD in Forno et al., 2012b). Numerous doubled ridges, minor scarps, and 


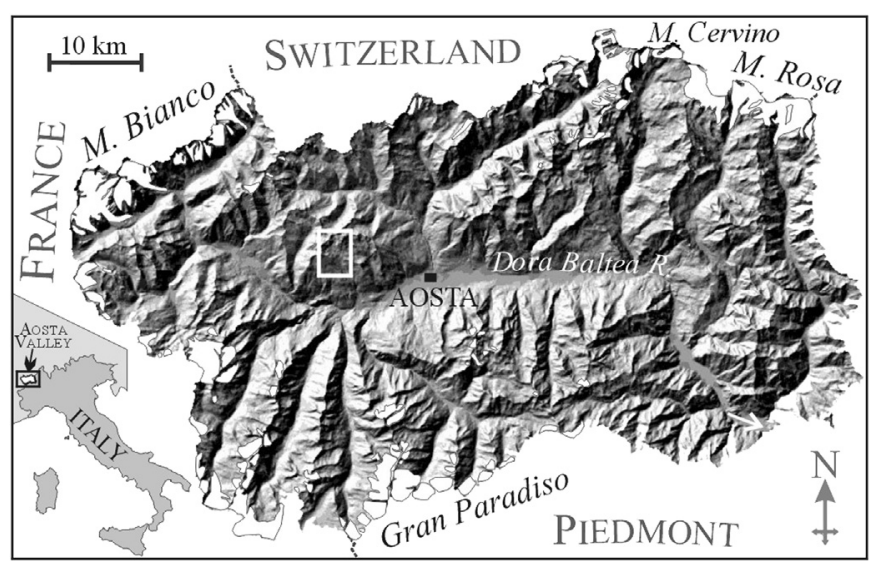

Fig. 1. Digital model of the Aosta Valley: the glaciers are shown in white. The square represents the area mapped in Fig. 3.

both longitudinal and transversal trenches have been mapped in the Becca France sector. A large historical landslide has also been described in the Clusellaz Valley under the Becca France watershed.

Current geological research in the Aosta Valley, which is still in progress, indicates that gravitational landforms also exist in the Plan di Modzon area, on the extension of the Becca France doubled ridge (Forno et al., 2004, 2012a). A single wide DSGSD from Becca France to Pointe Leysser therefore exists. The typical morphology of this plan, wide, slightly sloping, highly suspended over the Aosta Valley floor and deformed by a deep-seated gravitational slope deformation (DSGSD), represents a very unusual context within the Aosta Valley. This morphology favors tourism in the area for trekking, Alpine skiing and mountain biking, now facilitated by a mountain retreat (Mont Fallère Hut).

The archaeological data reported in this paper suggest that the Plan di Modzon area represents a very specific site for ancient human establishment. In view of these peculiarities, the Plan di Modzon can be regarded as favorable for investigating the possible correlation between gravitational phenomena and human settlements. The research conducted in this work was undertaken through an active collaboration between the Aosta Valley Region (Soprintendenza per i beni e le attività culturali), the University of

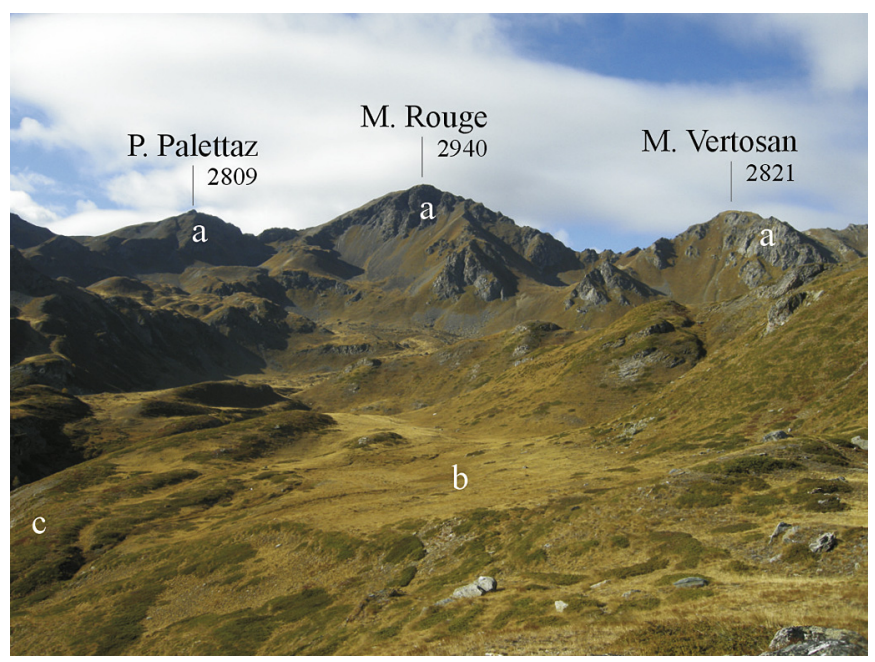

Fig. 2. Overall view of the studied high mountain site. The arched high rocky ridge (a) (M. Palettaz, M. Rouge and M. Vertosan), the Plan di Modzon (b) (2300-2260 m), showing open surfaces and wide viewing, and the high scarp of Verdjouan (c) are indicated.
Ferrara for the archaeological aspects, and the University of Turin for the geological features.

\section{Methods}

Both the bedrock and Quaternary cover have been mapped in the areas around the sites at a scale of 1:5000. Several glacial and gravitational landforms have also been mapped, aided by the analysis of aerial photographs. A stratigraphical reconstruction of sites MF1 and MF3 was also performed during the archaeological investigations in 2011 and 2012, to evaluate the geoarchaeological context. The collected data were used to draw the longitudinal profiles and cross-sections. In the field, regional foliation in the bedrock, indicated by the most evident metamorphic surface of the rocks, is generally oriented sub-parallel to the lithologic layering. The difficulties encountered were essentially related to the scarcity of Quaternary sediment outcrops, connected to the gently sloping morphology and the widespread distribution of colluvial deposits.

The archaeological survey has involved the research of promising areas, identified through detailed investigation (Raiteri et al., 2008; Raiteri, 2009) of the environment features supporting the settlements and their comparison to known models for the same altitude range (Dalmeri et al., 2001). The research group collected all of the archaeological materials, cataloging them according to the stratigraphic level. The possible artifacts already collected in the field have been subjected to an initial typological analysis to preliminarily identify cultural features and to determine which areas are suitable for subsequent research.

All of this evidence was mapped using a GIS (geographic information system). The GPS (global positioning system) was used to locate the sectors for investigation within the kilometer network of the UTM-ED50 conform projection (related to the UTM system in the ED50 geodetic reference system). These sites are successively located by topographical landmarks.

An archaeological excavation consists of the progressive removal of levels (named a stratigraphic unit, SU) in reverse of their order of deposition. The sector being investigated, once identified and delimited, is divided into $1 \mathrm{~m}$ by $1 \mathrm{~m}$ squares (connected to some topographical landmarks) and further divided into $0.50 \times 0.50 \mathrm{~m}$ sectors (named A, B, C and D).

The removed sediments are washed (using sieves with $1.5 \mathrm{~mm}$ mesh) and examined in detail. The observed artifacts have been listed with the location, year, site, square, sector and SU of their discovery. These data have been integrated with the sedimentary description and the disposition of the artifacts and archaeological preserved structures. The usual planimetric measurements for each levels, cumulative sections and photographs have also been obtained. Several radiocarbon (AMS) dates, obtained from charcoal samples in the MF1 and MF3 sites, were available for the chronostratigraphic reconstruction (Guerreschi et al., 2010).

\section{Mesolithic human settlements on the southern slope of the Alps}

Significant climatic events occurred in the beginning of the eighth millennium BC in Europe that are responsible for profound changes in the distribution of natural habitats and ecological niches (Guerreschi, 1992; Evin et al., 1994; Broglio and Lanzinger, 1996; Dalmeri and Lanzinger, 2001; Davis et al., 2003; Tinner and Theurillat, 2003; Jalut, 2005; Aceti, 2006; Brugiapaglia, 2007; Badino et al., 2010; Pini et al., 2011). These climatic features certainly conditioned the settlement choices and subsistence strategies of Mesolithic groups (Kozlowski, 1973; Bagolini, 1980; Broglio, 1980; Angelucci, 1997; Guerreschi, 1998). Research concerning the Trentino-Alto Adige region (eastern Alps) indicates that the most advanced Mesolithic 
groups were well adapted to new biotypes, having occupied highly productive ecological niches (Dalmeri et al., 2001). They developed complex settlement strategies and occupied the territory in a "moving logistics" way. The base camps (valley floor sites) became progressively more permanent and populated throughout years. The settlements sometimes had remarkable continuity, lasting hundreds of years. These groups lived in these sites with a division of their main activities. A number of short-term seasonal sites was also present (mountain sites) for specific hunting activities.

This settlement system, with its semi-permanent base camps and short-term seasonal camps, remained constant over time with only modest changes. The Mesolithic groups in the Adige Valley occupied the rock shelters along the slope of the valley and hunted the local animals. Deer, roe deer and wild boars were hunted in the forests around the valley floor lakes. Fish, shellfish and turtles were remarkable food supplies from the lakes. Chamois, ibexes and marmots were hunted in the plateaus above. In the high valleys, these human groups were located near the boundary between forests and grasslands at altitudes between 1900 and $2300 \mathrm{~m}$ with short-term seasonal camps. Early Holocene humans hunted deer around the camps and moved from these locations to hunt ibex at higher altitudes.

\section{Geological and morphological features}

The studied area is located on the southern side of the Mont Fallère into the Verrogne Valley floor, which is a left tributary valley of the main Dora Baltea Valley (Fig. 2). Within the arched high rocky ridge between P. Leysser and M. Fallère ( $\mathbf{a}$ in Figs. 2 and 3) a main gently sloping surfaces occurs in the Verrogne Valley floor, the Plan di Modzon (b in Fig. 2) (2300-2260 m), perched above the Aosta Valley floor. This plan is bordered downstream by the scarp of Verdjouan (c in Fig. 2), approximately $250 \mathrm{~m}$ high, that represents a glacial threshold separating the upper Verrogne Valley from the lower one (Fig. 3).

A well-articulated hydrographic network has been observed (Fig. 3). Three main watercourses occur in the upper Verrogne Valley floor, the western, intermediate and eastern T. Verrogne, which are separated by low rocky ridges (Fig. 4A). These rivers consist of NWSE and WSW-ENE stretches that likely follow the primary fracture systems. Several tributary rivers also occur and form an embryonic hydrographic network. The Plan di Modzon sector is weakly cut by these watercourses (Fig. 4C). Along the Verdjouan scarp, they are deeply entrenched in rocky gorges (Fig. 4E). Two NW-SE and one WNW-ESE trending short incisions also occur between the eastern and western T. Verrogne, at present without any waterways.

In detail, the eastern T. Verrogne is located near many archaeological sites and flows into the deepest trough, where a large depression occurs, partly filled by a wide alluvial fan (see b in Fig. 14). This watercourse deepens downstream and cuts a gorge into the Verdjouan scarp. Strictly speaking, only the area to the left of the eastern T. Verrogne incision is named Plan di Modzon on official regional maps. In this work, this toponym is extended to the entire Verrogne valley floor sector, 2260-2300 $\mathrm{m}$ in elevation (Fig. 11).

\subsection{Metamorphic bedrock}

The Plan di Modzon is located along the tectonic contact between the Gran San Bernardo Nappe, referred to Middle Penninic Domain, and overlying calcschist unit of the Piedmont Zone, referred to the Upper Penninic Domain (De Giusti et al., 2004). Both units, belonging to the axial zone of the Western Alpine chain, show a blueschist metamorphic imprinting. The Gran San Bernardo Nappe outcrops into the northwestern sector of the investigated area and consists of a Paleozoic basement and discontinuous carbonate Mesozoic cover. The Paleozoic basement consists of micaschist, gneiss, and small bodies of greenschist, whereas the Mesozoic cover is represented by

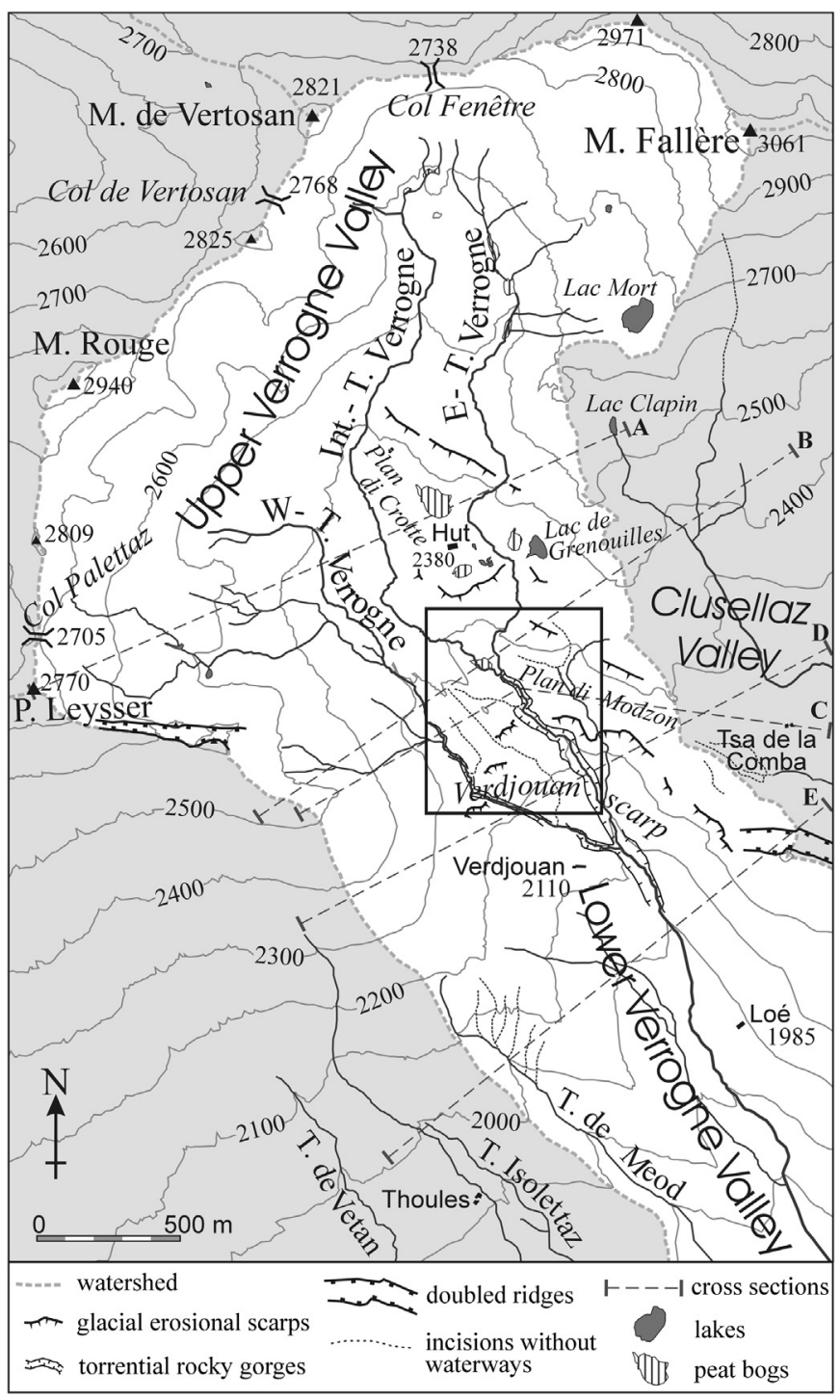

Fig. 3. Topographic map of the Verrogne Valley (white) with the cross section traces of Fig. 4. The upper valley floor is wide and shaped by three main watercourses, the western, intermediate and eastern T. Verrogne. The square represents the area mapped in Fig. 7.

metabreccia with carbonatic elements and white/gray dolomitic marble. The Piedmont Zone is represented by carbonate calcschist alternating with marble in decimetric thick layers.

In the Plan di Modzon area the bedrock is primarily represented by the Gran San Bernardo Nappe (Middle Penninic) that outcrops into the core of a NW-SE trending antiformal structure. The primary fracture systems are WNW-ESE, NW-SE, NE-SW and N-S trending. The tectonic contact between the Gran San Bernardo Nappe and the Piedmont calcschist, along the southwestern flank of the described antiformal structure, is partially reactivated by slide planes related to the P. Leysser DSGSD. Human settlements (sites MF1 and MF3) investigated in the Plan di Modzon area occur in the Gran San Bernardo rock types, influenced by glacial erosion.

\subsection{Glacial sediments and landforms}

The dominant morphology of the Plan di Modzon area consists of long, narrow ridges separated by troughs parallel to the valley. The rounded form of these ridges indicates a subglacial origin. The wide distribution is indicative of their Last Glacial Maximum (LGM) 


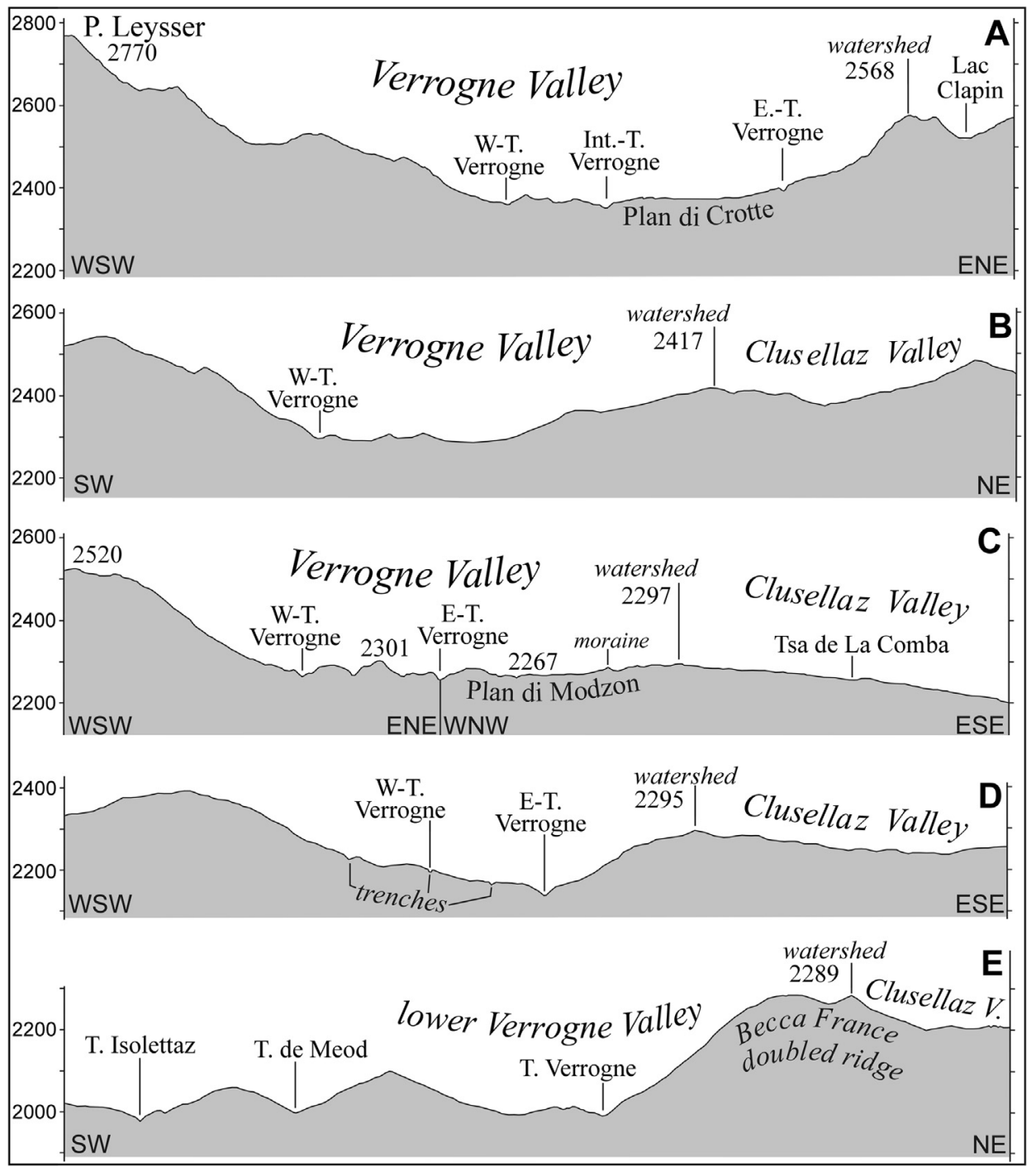

Fig. 4. Topographic cross sections of the area (see traces in Fig. 3). The Verrogne Valley shows a wide floor, separated from the Clusellaz Valley by a low watershed.

and Lateglacial age. The glacial deposits in the Plan di Modzon are poorly preserved on the rounded ridge crests. They are represented essentially by sporadic, small ( $1 \mathrm{~m}$ in size at most) and partially rounded erratic blocks composed of the Gran San Bernardo gneiss and micaschist. In the eastern sector, some bodies of marginal flow till are suggested by the presence of short and low lateral moraines. Their distribution indicates supply by the left lateral edge of the Verrogne Glacier, during a Lateglacial stadial.

Most commonly, thin debris-colluvial deposits cover the bedrock. They are composed of matrix-supported gravelly-silty sand and clast-supported silty-sandy gravel rich in angular clasts, and contain highly rounded and faceted gneiss clasts derived from subglacial deposits. These clasts are supplied by the local Gran San Bernardo bedrock. These sediments suggest that a thin and discontinuous subglacial cover was initially present, subsequently removed and reworked by surficial gravitational (small debris flows and rock falls) and colluvial processes.

The glacial cover in the area of investigation (now completely free of glaciers) is essentially linked to the past activity of the Clusellaz and Verrogne glaciers. Preliminary geomorphological study has allowed reconstruction of glacial history strictly driven by the P. Leysser DSGSD, responsible for the anomalous width, morphology and accessibility of the Plan di Modzon area. The presence of Becca
France and P. Leysser doubled ridges, on the two sides of the Verrogne Valley, indicates the previous continuity of the watershed between a single Verrogne-Clusellaz basin and the Dora Baltea Valley. Moreover, the absence of an evident divide between the Clusellaz Valley and the Verrogne Valley suggests that before and likely during the LGM the Verrogne Glacier flowed toward SE and was a tributary of the Clusellaz Valley (Fig. 5A and B). Finally, the cataglacial sequence in the lower Verrogne Valley indicates that, during the subsequent Lateglacial, the Verrogne Glacier flowed southward (Fig. 5C). Subsequently the DSGSD has evolved to form the present setting, favouring fluvial erosion (Fig. 5D).

Therefore, it is likely that the lower Verrogne Valley originated from a glacial diversion, that was responsible for cutting the original rocky watershed between the Dora Baltea Valley and the Clusellaz Valley (Fig. 5C). The recent age for this diversion is supported by the subsequent small erosional deepening of the Verrogne Glacier, indicated by: (i) the formation of a low watershed between the Verrogne Valley and the Clusellaz Valley (only a few tens of meters high); (ii) the location of the threshold shaped by the Verrogne Glacier (corresponding to the Verdjouan scarp) just upstream (no more than $300 \mathrm{~m}$ away) of the original watershed; and (iii) the morphology of the lower Verrogne Valley, scarcely deepened into the erodible calcschist involved in the DSGSD. 

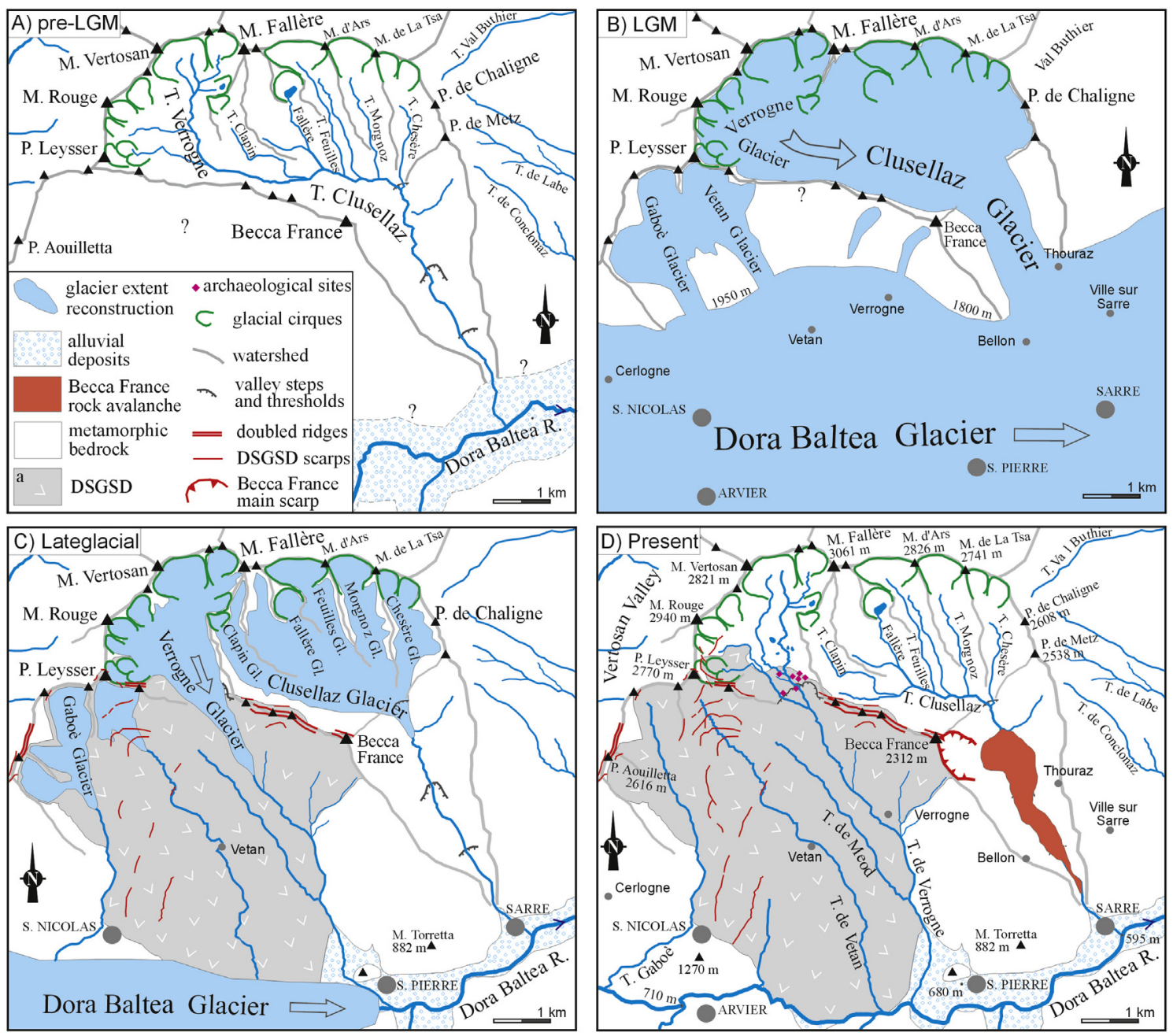

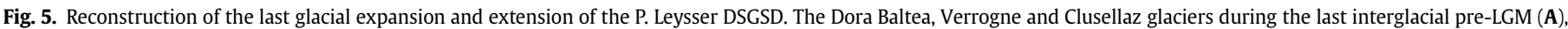

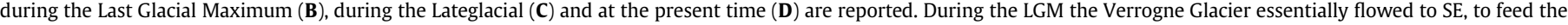

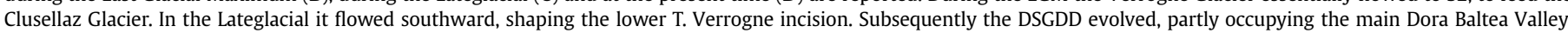

\subsection{Typical feature of a deep-seated slope gravitational deformation}

A deep-seated slope gravitational deformation (DSGSD) is an extended phenomenon (between some kilometers and some tens

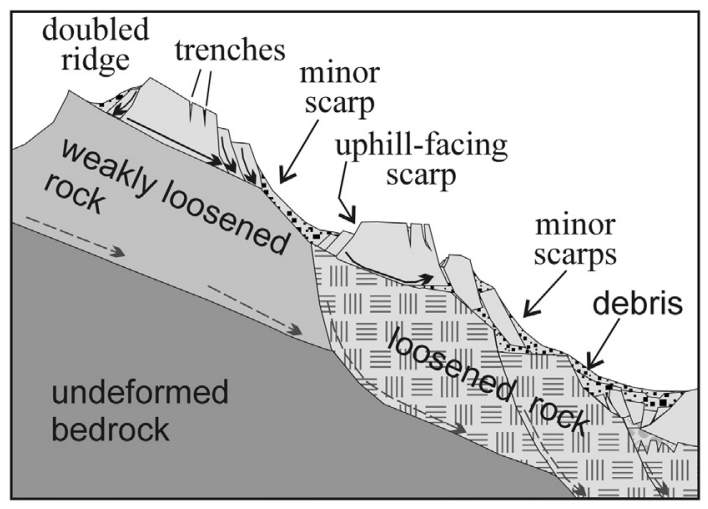

Fig. 6. Sketch of the features of a typical deep-seated gravitational slope deformation (DSGSD). Besides the variously fractured rocks, a doubled ridge, some minor scarps and trenches are reported. of square kilometers) common in many mountain regions and is particularly diffuse in the Alps. The entire affected area progressively slides in the downstream direction because of gravity. Generally, the DSGSD affects large thicknesses (some hundreds of meters) of bedrock with its Quaternary cover and evolves with very slow velocities (generally some mm/year) (Zischinsky, 1969; Crosta, 1996).

This gravitational phenomenon essentially creates a large body of highly fractured rocks, with most fractures open (loosened and weakly loosened rock in Fig. 6), which is responsible for both a substantial incoherence in the bedrock and several gravitational landforms of various sizes. These consist of several elongated depressions, some meters to hundreds of meters long and some decimetres to tens of meters deep, located at different altitude bands along the slope, which are defined as trenches. The trenches parallel to the contour lines are transverse to the movement direction (transverse trenches) and are usually more easily recognized because they are only slightly affected by remodeling. The trenches in the direction of movement (longitudinal trenches) are, however, less clear. Their extension along the line of maximum slope favours the concentration of surficial water and snow, which is responsible for the subsequent incision.

The entire slope of the DSGSD is affected by very steep sectors, referred to as minor scarps and uphill-facing scarps, with varying 


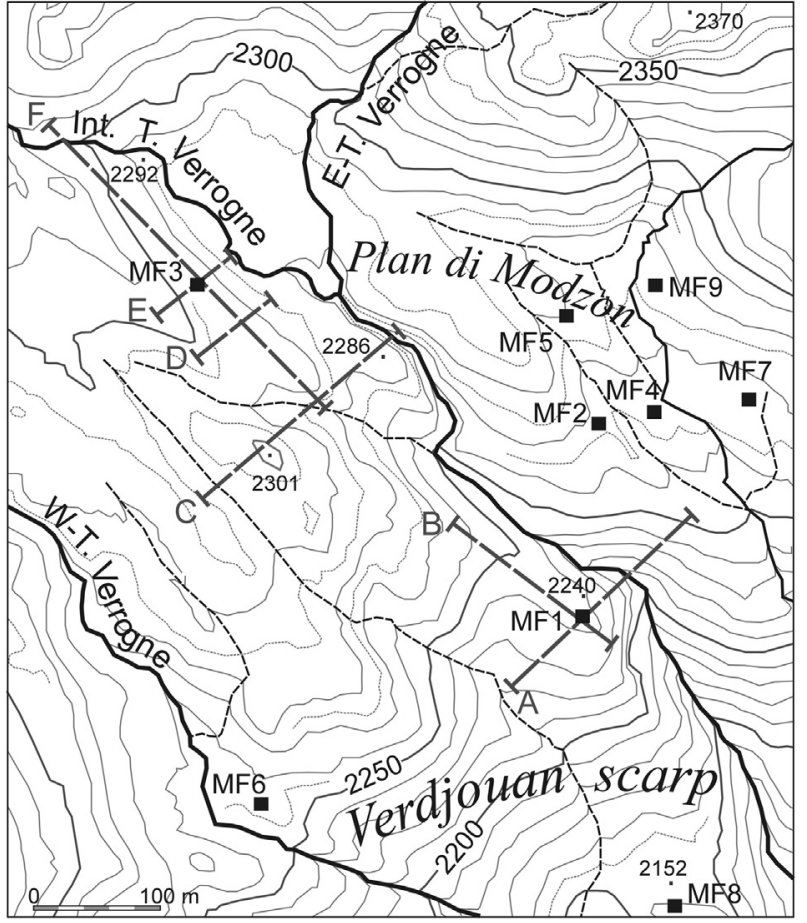

Fig. 7. Plan di Modzon topographical map. The traces of the cross sections and longitudinal profiles of Figs. 8 and 12 are reported throughout MF1 and MF3 archaeological sites. The other archaeological sites discovered (MF) are mapped.

size. The bedrock and Quaternary cover slide downstream along these scarps, to create a typical set of steps. Other elongated depressions along the ridge, directly below the watershed, are often remarkably long (several hundreds of meters) and deep (some tens of meters). Because they form parallel to the watershed, they create multiple ridges (doubled ridges).

The numerous fractures make the exposed rocks very unstable, which promotes numerous landslides. The strong incoherence of

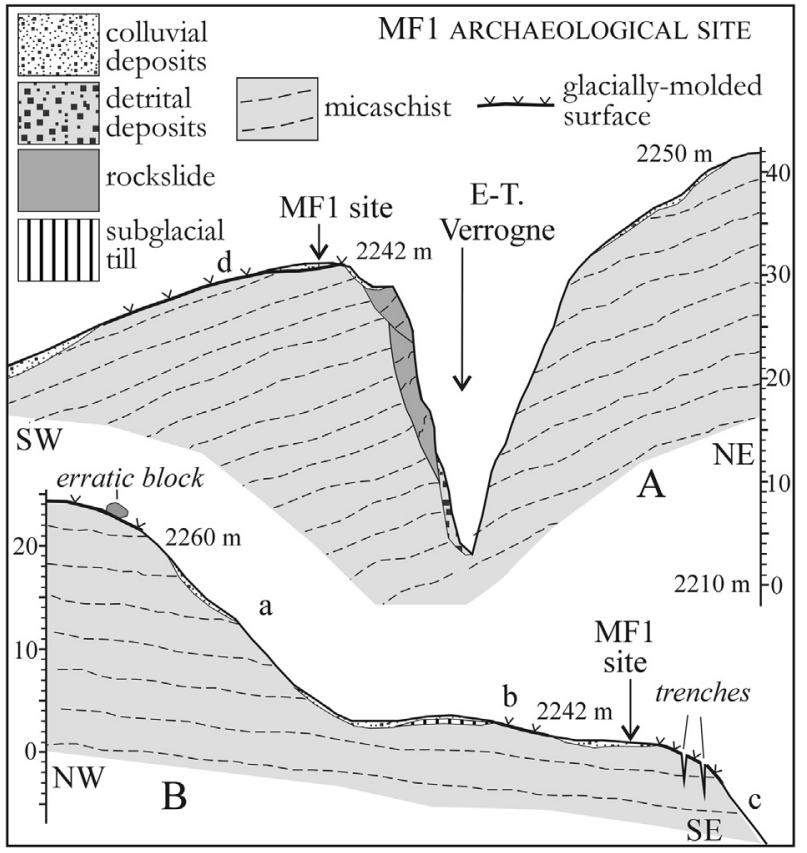

Fig. 8. Schematic geological profiles of the area across the MF1 site, located on a ridge slightly inclined (the explanation of letters $\mathbf{a}-\mathbf{c}$ is reported in the text).

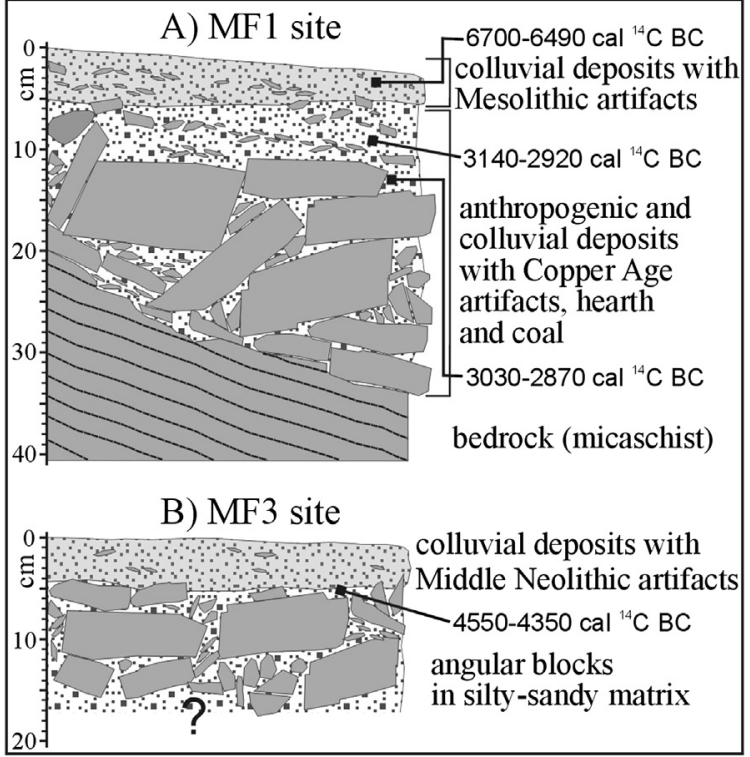

Fig. 9. Stratigraphic reconstruction of MF1 (A) and MF3 sites (B). In MF1 on the loosened bedrock a level of anthropogenic deposits occurs, with Copper Age hearth and charcoal, covered by colluvial sediments, with more ancient Mesolithic artifacts, forming a reversed archaeological sequence. In MF3 the colluvial cover contains only Middle Neolithic artifacts.
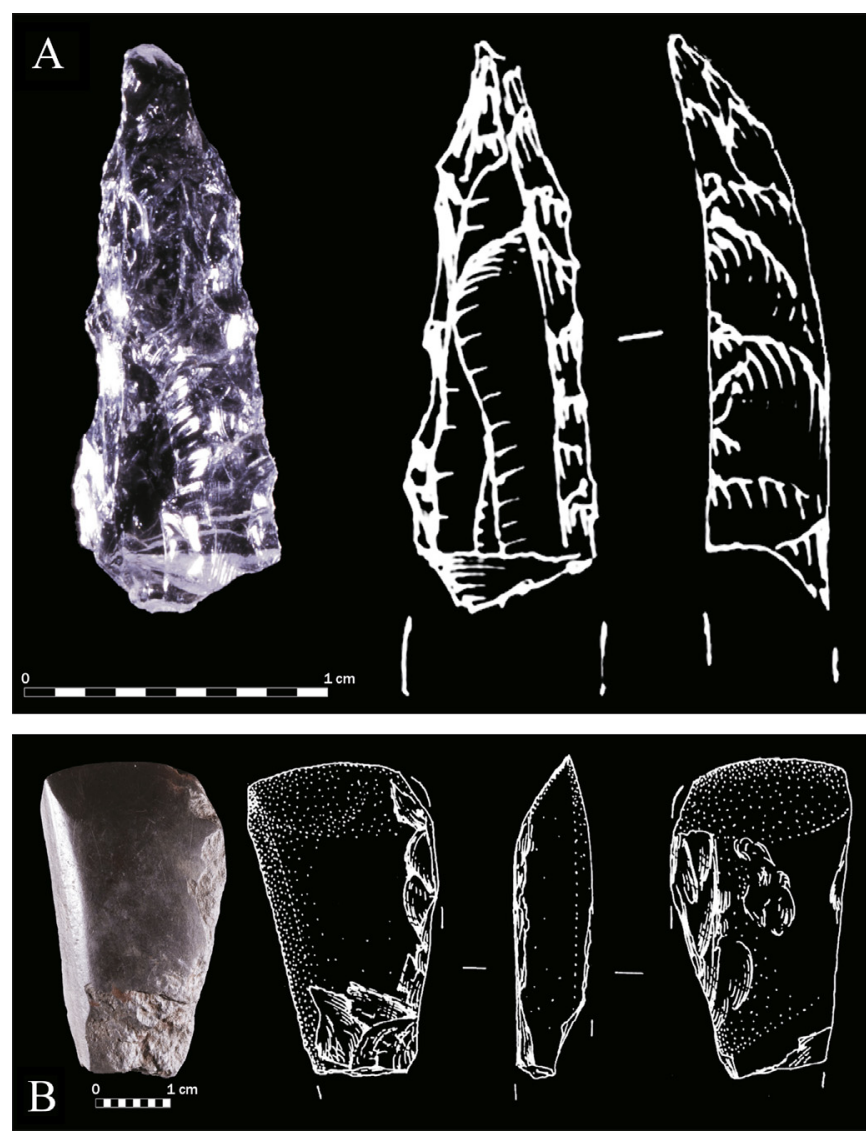

Fig. 10. Archaeological artifacts from the MF1 site. Fragment of double backed pointed microlith, rock crystal (Mesolithic) (A) and axe made of greenstone (Copper Age) (B) (Photo P. Gabriele, drawing G. Almerigogna). 


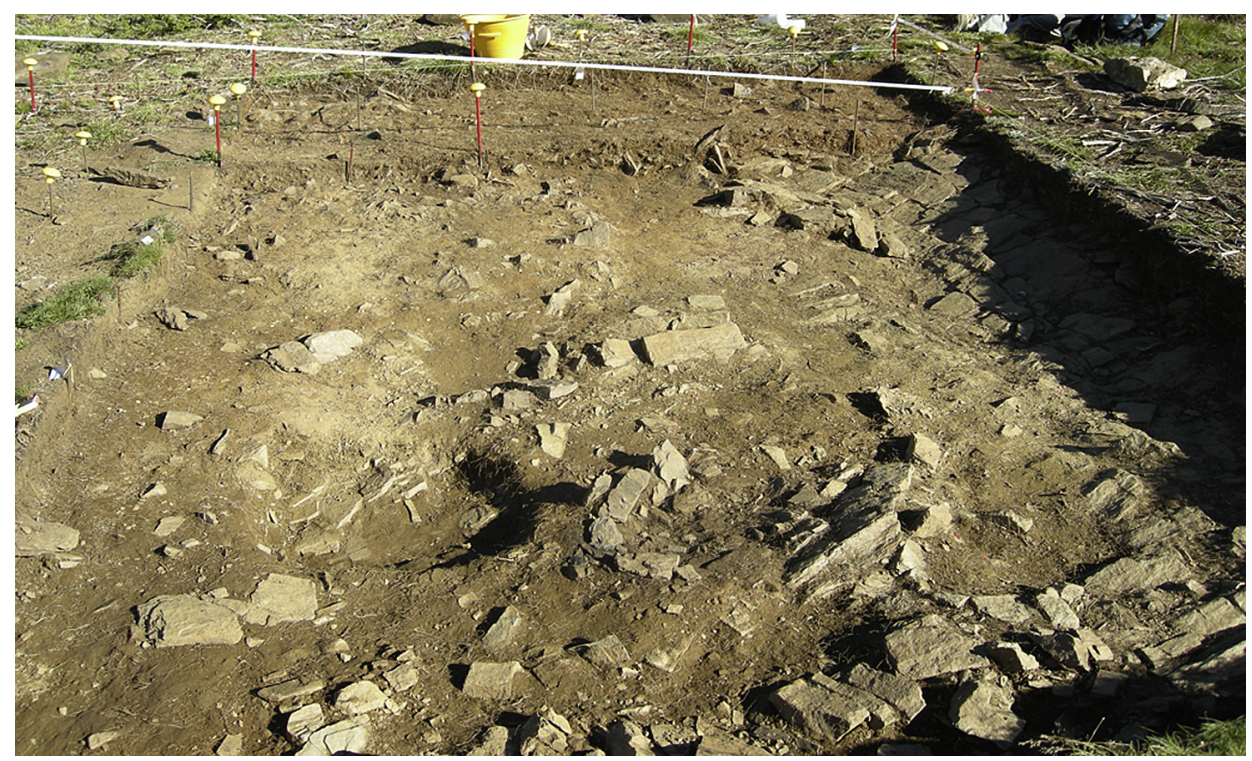

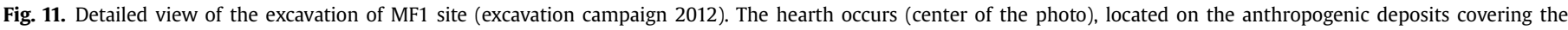
loosened bedrock.

the bedrock also favors both accelerated erosion and diffuse erosional phenomena. Finally, these features promote the diffusion of debris and colluvial sediments covering the bedrock and other Quaternary sediments over extensive areas.

The very wide area involved in the DSGSD often has an uncertain boundary with the surrounding sectors that is not deformed by gravitational phenomena. Elsewhere, an abrupt boundary consisting of a continuous arched scarp is located at the upper edge of this area. These features are similar to a detachment niche of a surficial landslide, except for their vastly larger size, which suggests they are the primary scarp of the DSGSD.

The DSGSDs are common phenomena in the Aosta Valley. The peculiarity of the DSGSD context, halfway between an in-place

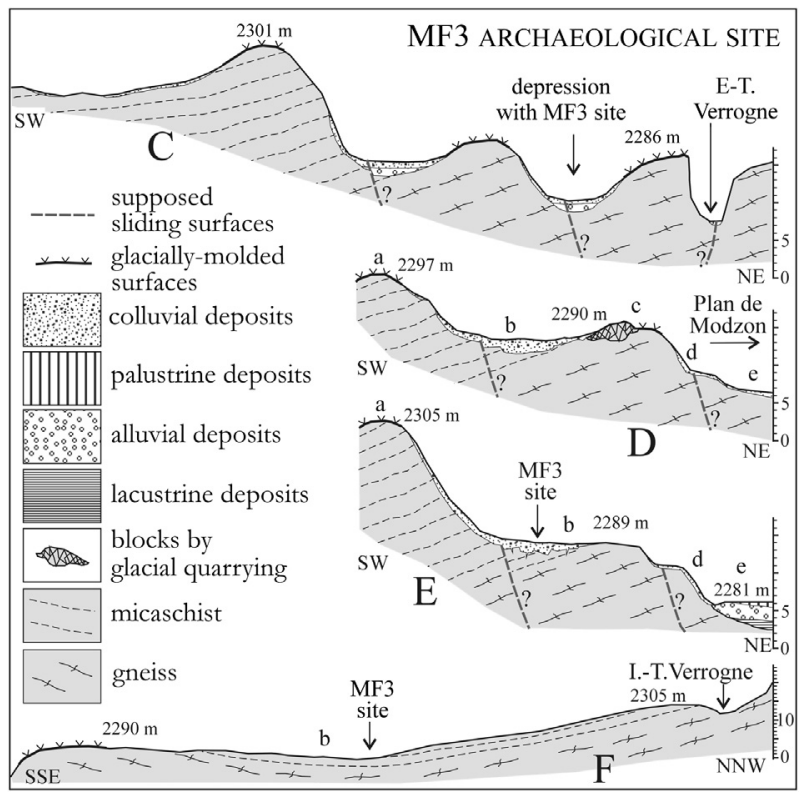

Fig. 12. Schematic geological profiles of the area across the MF3 site (the explanation of letters $\mathbf{d}-\mathbf{e}$ is reported in the text). The site occurs in a weak depression (b), shaped in the loosened bedrock and covered by a thin level of colluvium that contains Middle Neolothic artifacts. rocky slope and landslide body, has been responsible for its late detection and fragmentary mapping. Additionally, the gravitational deformation in the area of investigation has essentially not been reported in previous geological literature (Elter, 1987; Mortara and Sorzana, 1987).

\subsection{Plan di Modzon gravitational features}

A survey undertaken over the last few years in the middle Aosta Valley, which is still in progress, suggests that the Plan di Modzon area shows a typical morphological and geological context. This area consists of a slightly sloping (5\%) widespread valley floor (approximately $0.3 \mathrm{~km}^{2}$ ) and highly perched $(1500 \mathrm{~m}$ ) on the main valley floor, which represents a very specific place in the entire Aosta Valley.

The Plan di Modzon possesses an articulated morphology with elongated ridges, rocky scarps, and both elongated and occasionally close depressions (see Fig. 14). Most of these features have WNW-

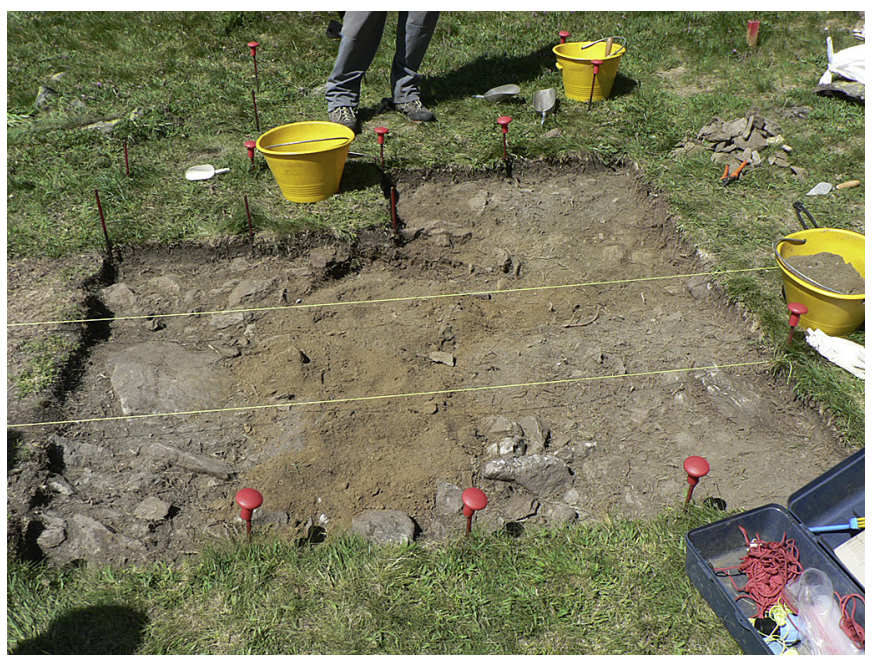

Fig. 13. Detailed view of the MF3 site (excavation campaign 2011). The yellowishbrown colluvium containing Middle Neolithic artifacts lies on gravitational deposits rich in angular blocks. 


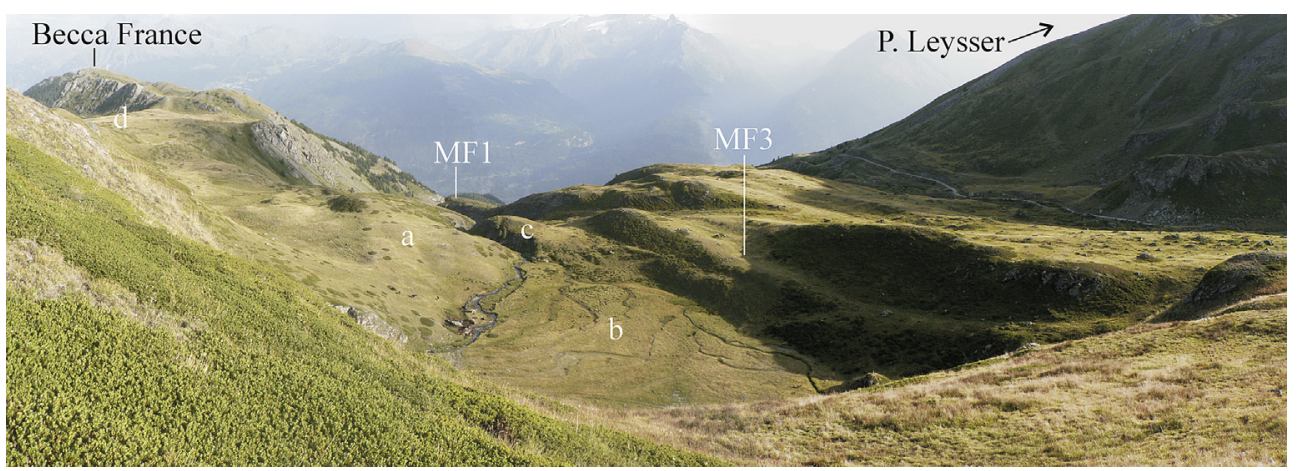

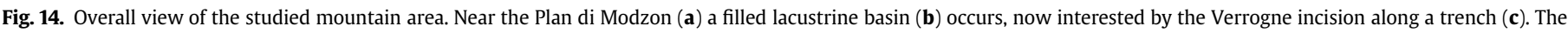
watershed between Clusellaz Valley and Verrogne Valley (d) is just pronounced.

ESE, NW-SE and NE-SW trends. The ridges and scarps are essentially shaped in the bedrock, while the depressions are partially filled with Quaternary sediments (Fig. 12C). The ridges often preserve diffuse relics of the glacial shaping (roches moutonnées). Only a few low ridges are composed of glacial sediments and form small moraines. Extended areas of highly fractured rocks also occur. Here, several very pervasive and partly open fractures make the bedrock non-cohesive, which simulates the presence of debris sediments.

The elongated depressions, which often host the watercourses, are bordered by subvertical walls shaped in the bedrock (Fig. 8A). They are several tens of meters long and meters deep, and occur along the primary fracture systems. Even though these landforms may be confused with torrential incisions, their narrow and straight shape suggests they are gravitational trenches. Additionally, the WNW-ESE depressions are parallel to the previously described doubled ridges of the Becca France watershed (Forno et al., 2012b). These features, which are orthogonal and parallel to the DSGSD movement respectively, suggest that the trenches are transverse (WNW-ESE and NE-SW) and longitudinal (NW-SE) trenches, subsequently re-used by the watercourses.

Both the overall and detailed morphologies of the Plan di Modzon are expressions of gravitational phenomena. This area is located directly WNW of Becca France, where a set of wide WNWESE doubled ridges occur (Forno et al., 2012b). The Verdjouan scarp is also roughly aligned with the doubled ridges between Becca France and P. Leysser. The location and diffuse gravitational landforms (minor scarps and trenches) suggest that the investigated area represents an extension of the P. Leysser DSGSD (Fig. 5D).

Gravitational evidence shows various relationships to glacial modelling. In detail, the gravitational evidence partly predates the glacial landforms (the glacial landforms re-use the gravitational ones) and partly subsequent (the gravitational landforms cut the glacial evidence). Postglacial trenches cut both the glacial deposits and forms, and are the more remarkable gravitational evidence.

The evolution of the P. Leysser DSGSD has likely driven the features of the glacio-hydrographic network. The DSGSD was likely reactivated due to slope unloading connected to the withdrawal of the Dora Baltea Glacier (Dal Piaz et al., 2010). In detail, the Verrogne Glacier diversion was promoted by this DSGSD. Moreover, the lower Verrogne Valley can be interpreted as a longitudinal trench enlarged and modelled by the inserted Verrogne Glacier ( $\S 4.2$ ).

\section{Results from the first geoarchaeological investigations in the Plan di Modzon area}

Two excavations were conducted, during summer 2011 and 2012, in the Plan de Modzon area to investigate Mont Fallère 1
(MF1) (16 $\mathrm{m}^{2}$ and 25-30 cm deep) and Mont Fallère 3 (MF3) $\left(9 \mathrm{~m}^{2}\right.$ and $10-15 \mathrm{~cm}$ deep).

\subsection{Site $M F 1$}

The area of the archaeological investigation for site MF1 occurs at the southern edge of the Plan di Modzon approximately $2242 \mathrm{~m}$ a.s.l. along the eastern $\mathrm{T}$. Verrogne downstream of the confluence with the intermediate T. Verrogne (Fig. 7). In detail, this archaeological site is located on the summit of a NW-SE ridge approximately $100 \mathrm{~m}$ long. It is currently highly perched on the eastern $\mathrm{T}$. Verrogne incision, which appears to be approximately $25 \mathrm{~m}$ deep (directly NW of the site) and $40 \mathrm{~m}$ deep (directly $\mathrm{E}$ of the site). This incision is elongated along a longitudinal trench linked to the described DSGSD.

The ridge hosting site MF1 slopes very gently (5\%) in a NW-SE long section (b in Fig. 8B). The site is located directly below an approximately $20 \mathrm{~m}$ high slope ( $\mathrm{a}$ in Fig. $8 \mathrm{~B}$ ) that divides this ridge from Plan di Modzon. The described ridge is also bounded downstream by an approximately $100 \mathrm{~m}$ high slope (partly represented as $\mathbf{c}$ in Fig. 8B).

The investigated ridge has a very asymmetric cross section (Fig. 8A). The southwestern site appears to slope relatively gently (d in Fig. 8A), whereas the northeastern site, which overlooks the deep incision of the eastern $T$. Verrogne, consists of a very abrupt rocky scarp. A lowered sector can be found in the torrential incision.

In detail, the upper slope (2260-2245 m) (a in Fig. 8B) is eroded into the bedrock (micaschist) and shows a thin covering of decimetric elements of micaschist, from angular to rounded. Locally, the presence of some boulders of gneiss or some other non-local provenance lithotypes suggests the presence of a subglacial cover (erratic block in Fig. 8B).

The ridge hosting site MF1 (2245-2240 m) (b in Fig. 8B) was eroded into the bedrock and consists of a millimeter compositional layering of micaschist with light quartz rich levels, and dark and white mica and chloritoid rich layers. More than a decimetric level of graphitic phyllite is also present. The regional foliation dips 25$30^{\circ}$ towards the SW. This ridge is formed by a glacial erosional surface parallel to the foliation, which suggests the re-use of this structural element (d in Fig. 8A). A limb of gravel also occurs on the bedrock and consists of rounded centimetric to decametric pebbles prevalently formed of gneiss and quartzite mixed in an abundant sandy-silty matrix. Some elements are typically faceted. These sediments are yellowish-brown (10 YR 4/4) across the entire thickness, which suggests incipient weathering to forming a soil. Although no significant outcrop was observed, this facies is consistent with the features of lodgment till. The rounded features of the ridge, except for the scarp along the eastern T. Verrogne, are related to glacial erosion. 
A thin cover of the prevalent yellow sandy-silty sediments occurs on the bedrock, with some $5-25 \mathrm{~cm}$ of coarse angular elements (micaschist). These fine sediments were likely derived from the anthropogenic reworking of the glacial cover as suggested by their texture and yellowish-brown color (10 YR 4/4), similar to the subglacial sediments (Fig. 9A). The elements are also indicative of bedrock clasts with various arrangements that have been removed by ancient human activity. This carryover was designed to create a horizontal plane for the settlement, subsequently covered by a very thin yellowish colluvial layer.

The sequence is covered at the top by local brown silty-sands (7.5 YR 4/4). Their surficial distribution and fine texture suggest a colluvial genesis. The source of this colluvium is probably the weathered bedrock with similar color, diffuse on the ridge directly upstream.

The sector of the ridge under site MF1 (2240-2230 m) (c in Fig. 8B) is a scarp shaped into the fractured bedrock (micaschist), which diffusely outcrops into the eastern $\mathrm{T}$. Verrogne incision. This scarp is involved in some trenches, some meters deep.

The site MF1 has Mesolithic artifacts (about 3000) (Fig. 10A) obtained from rock crystal in nearly all cases. A few flint manufacturing residues also occur. The retouched artifacts (94) indicate a probable Sauveterrian phase. Some double back, back and cutting and triangular artifacts are the most indicative. An age of 6700-6490 cal BC (LTL4006A CeDaD, Q963B) dates these remains.

This site was subject to erosion that removed most of the Mesolithic material. The remaining artifacts were linked to a colluvial phenomenon, responsible for the limited reworking and current distribution in the secondary arrangement of the upper level (SU 40). The rock crystal was likely supplied directly from the local Penninic bedrock or its glacial cover. The less abundant flint artifacts were imported from other locations.

The MF1 site yielded archaeological evidence of Eneolithic age: a layer with evident traces of settlement and use (rubefied areas, charcoal accumulations), superimposed by a hearth (US 17), partially investigated, preserving a huge amounts of charcoal inside a cuvette, delimited by lithic fragments set in the ground. Ages of 3030-2870 cal BC (LTD4390A CeDaD, MF1 Q633A US 17) and 2620-2400 cal BC (LTD4391A CeDaD, MF1 Q633D US 17) were obtained from charcoal remains. Layer US 21 (2500-2270 cal BC; LTD4392A CeDaD, MF1 Q734C) yielded an Eneolithic axe and a hazel nut (2795-2562 cal BC; Ua-38471, MF1 Q733C). A charcoal from a colluvial layer (SU28) founded in the excavations of 2011 gave an age of 3140-2920 cal BC (LTL12386A CeDaD, MF1 Q534B US 28), partly corresponding to the dating range of the hearth. Excavations carried out in 2010 document a stratigraphy consisting of an area of burnt sediment (US 34), hiding a hearth (US 17) and testifying to a later phase of use. The superimposition of the burnt sediment (US 34) and the hearth (US 17) may indicate the existence of an area with a specific functional destination, possibly connected to shelter. The prolonged settlement of the high-altitude site may point to activities linked to seasonal transhumance. Therefore, archaeological data and ${ }^{14} \mathrm{C}$ ages indicate that the sequence is reversed: the younger settlement (Copper Age) is at the base, while reworked (colluviated) Mesolithic artifacts are at the top (Fig. 9A).

\subsection{Site $M F 3$}

The area of archaeological investigation at site MF3 occurs in the Plan di Modzon at approximately $2292 \mathrm{~m}$ a.s.l. along the intermediate T. Verrogne, upstream of the confluence with the eastern $\mathrm{T}$. Verrogne (Fig. 7). This site was been involved in an excavation campaign (2011).

The site is located along a low depression (less than $1 \mathrm{~m}$ deep) (b in Fig. 12E), elongated in the NNW-SSE direction and bordered by surrounding rounded ridges (a in Fig. 12E). Evidence of this depression increases toward the SE where relatively more marked ridges occur (a and c Fig. 12D). Some supposed gravitational trenches were observed along the incision of the eastern T. Verrogne next to the site.

The depression hosting the site MF3 posses a very gentle slope (5\%) in a NNW-SSE long section (b in Fig. 12F). It occurs directly above an approximately $3-5 \mathrm{~m}$ high scarp ( $\mathbf{d}$ in Fig. 12D and E) that divides the described depression with another, wider depression $(\mathrm{q}$ 2281, e in Fig. 12D and E) bounded downstream by a gentle ridge with an asymmetric cross section (q 2286 in Fig. 12C and see $\mathbf{c}$ in Fig. 14). This depression is likely filled by lacustrine sediments that are further buried by torrential sediments forming the wide alluvial fan of the eastern T. Verrogne (see b in Fig. 14).

In detail, the described ridges (Fig. 12C) are shaped in the bedrock and consist of micaschist and gneiss. Micaschist has a millimeter compositional layering with light, quartz-rich levels and dark layers rich in white mica and chloritoid. Gneiss, which contains variable amounts of epidote, posses a fine-grained texture and gray color. These rocks are homogeneous in composition and have poor metamorphic layering. A body several meters thick of greenschist within micaschist also occurs in the ridge $(2301 \mathrm{~m})$. The regional foliation in this area dips approximately $20^{\circ}$ toward the south.

Gneiss outcropping from the ridge ( $2286 \mathrm{~m}$ ) southeast of site MF3 to the eastern T. Verrogne have a regional foliation that dips approximately $30^{\circ}$ to the west. More decametric-scale NW-SE wide synformal folding was responsible for the orientation change of the regional foliation. Site MF3 is located near the fold hinge, where the regional foliation shows a sub-horizontal trend.

The very slight depression hosting the site reveals coarse sediments consisting in angular block in sandy-silty matrix covered by a thin layer of fine sediments with some angular clasts some centimeters in size. These sediments are yellowish-brown (10 YR 4/4) throughout the entire thickness. This cover is also thought to have formed from colluvial processes that partly filled the original depression. Some angular micaschist boulders locally occurred on the surface of the depression.

The archaeological artifacts of MF3 (Fig. 13) were found directly below the grass, associated with colluvial sediments that likely reworked the weathered bedrock (Fig. 9B). These artifacts (about 1400) were obtained from rock crystal, related to the Middle Neolithic, including some retouched (14). This finding agrees with the age of a charcoal fragment dated to $4550-4350$ cal BC using the radiocarbon method (AMS) (LTL12268A CeDaD, Q650A US1). The low number of retouched artifacts did not permit further evaluation.

\section{Results and discussion}

The Plan di Modzon area has a typical morphology, unusual in the entire Aosta Valley. This morphology shows the following features:

- wide and slightly sloping surface (Plan di Modzon, a in Fig. 14);

- absence of a remarkable watershed between the Verrogne Valley and the Clusellaz Valley (d in Fig. 14);

- very irregular morphological details with ridges and depressions of varying size (ridged and grooved morphology, $\mathbf{d}$ in Fig. 2);

- presence of surrounding mountains with good visibility (a in Fig. 2);

- location highly hanging on the main valley through the high Verdjouan scarp (e in Fig. 2);

- directly overlooking the main valley floor. 
This area has very different features than other closer and deeper tributaries of the Aosta Valley. The described morphology is connected to geological conditions essentially represented by the following:

- the Verrogne Glacier diversion favored by the DSGSD (Fig. 5C);

- the location along the western extension of the Becca France doubled ridges (Fig. 3);

- the diffusion of very fractured rocks.

The primary cause of this very specific morphology is, therefore, connected to the occurrence of glacial shaping within a DSGSD sector.

With regard to the prehistoric settlements, the main consequence of the deformation of the Plan di Modzon area by the DSGSD is the presence of a wide and slightly sloping area at a high elevation (2240-2300 $\mathrm{m}$ a.s.l.) with both direct and easy access from the Aosta Valley (700 m a.s.l.). In detail, the Plan di Modzon is much wider and higher than corresponding sectors in other glacial tributary valleys. This difference formed because the upper Verrogne Valley was not a hanging valley (as it is currently) before the LGM, but was previously the head of the Clusellaz Valley (Fig. 5A). The Verrogne-Clusellaz basin was separated from the Dora Baltea Valley by the Becca France-P. Leysser rocky watershed. The Verdjouan passage was opened by the Verrogne Glacier through this divide (Fig. 5C), consisting of rocks which had been weakened by the DSGSD. The main consequence of this glacial evolution was the formation of a redoubled valley floor hanging above the main valley.

Generally speaking, mountain areas of the same altitude can only be reached with great effort by climbing a long valley floor that is locally deep, narrow and blocked by steep rocky steps. Alternatively, these areas can be reached by crossing the watershed through a very high mountain pass. The Plan di Modzon area was, instead, directly reachable from the main valley through the Verdjouan scarp. The outlet of the upper Verrogne Valley is simple to reach from the Dora Baltea Valley side because it has a relatively low average slope and numerous, easy to climb steps connected to the P. Leysser DSGSD.

Moreover, the lack of a significant left (eastern) flank for the upper Verrogne Valley above the Plan di Modzon, protects this area from the direct effects of debris flows and avalanches. This area is, therefore, different from other glacial hanging valleys, which have floors widely subjected to natural hazards. In addition, the local valley floor has a typical morphology of elongated low areas, safe from floods, alternating with depressions through which floods are conveyed.

Archaeological site MF1 has returned a lithic industry of rock crystal (hyaline quartz) referred to the ancient phase of the Mesolithic (Sauveterrian) and a series of archaeological settlement evidence referred to the Copper Age (Fig. 10). The more recent archaeological artifacts (Copper Age) were found in anthropogenic deposits on top of the bedrock. The more ancient artifacts (Sauveterrian) were discovered above these in the thin colluvial covering from reworked weathered bedrock (micaschist). This distribution of the collected artifacts creates a reversed stratigraphy formed by the colluvial reworking of the bedrock weathering products containing the more ancient archaeological remains (Fig. 9A).

Archaeological site MF3 had also returned a lithic industry of rock crystal referred to the Middle Neolithic. These archaeological artifacts were associated with colluvial sediments covering the bedrock (Fig. 9B). The morphology (slightly sloping surfaces, open ridges, scarps and irregular topography) most likely favored ancient human settlements for the following reasons:
- the presence of open surfaces and wide viewing (both upward and downward);

- the presence of abundant water both from various primary watercourses in the valley floor (hosted into the trenches linked to DSGSD) and lakes (hosted in closed depressions linked to subglacial erosion);

- the absence of debris flows and avalanches close to the central and distal sectors and connected to the wide valley floor with its elongated elevations;

- the possibility of hiding within irregularities when approaching animals.

These features and the nearness of the upper edge of the woods contributed to create an environment favorable for ancient humans. Some archaeological settlements were also found in other sites within the Alps at the same altitude range with similar morphological and vegetation features (Dalmeri et al., 2001). It is likely that this high site perched on the main valley floor and easy accessibility especially favored ancient human settlements. This ancient human presence is also more diffuse along the lower edge of the Plan di Modzon, where the debris flows and avalanches are probably less dangerous than at the outlet of the tributary basins. Settlements were also built near the watercourse but not within the incisions, which periodically suffer flooding.

The T. Verrogne appears to be highly incised in proximity to site MF1. It is very unlikely that the ancient population was located on the edge of this incision. The high scarp directly next to this site, was most likely formed by torrential erosion and developed in the period subsequent to the use of this site.

\section{Conclusions}

The P. Leysser DSGSD interacted with glacial erosion, contributing to create very favorable conditions for prehistoric settlements in the Plan di Modzon area. The evolution of the Verrogne Glacier promoted by the DSGSD gave rise to a direct passage from the main valley to the exceptionally wide Plan di Modzon. The DSGSD also produced a gentle-dipping Dora Baltea Valley side with a flight of step morphologies that promoted a gradual ascent and easy accessibility.

The presence of a large valley floor with a ridged and grooved morphology offered wide surfaces protected from geological hazards (mainly alluvial) as a result of the glacial erosion of gravitationally deformed bedrock that followed the openings of new trenches. In conclusion, the advantages of the Plan di Modzon place were easy access from the main valley to a wide high altitude area, that is relatively sheltered from geological hazards typical of high mountain areas. Therefore, deep gravitational phenomena were partly responsible for the human settlements.

The first conclusions of the reported data are conditioned by the small number of ancient sites from the Holocene identified in the southern slope of the Western Alps. The data from the Mesolithic collected at site MF1 are of primary relevance for reconstructing the lifestyles and environments related to the hunter-gatherer communities inhabiting the area after the glaciers retreated. Site MF1 also provides an interesting chronology for the Copper Age (31402270 cal BC), which corresponds to the cultural area of SaintMartin-de-Corleans; this area near Aosta is now a museum. More precise chronological data on the Plan di Modzon findings could be derived from the preliminary palaeobotanical research conducted in a peat bog (2365 m S of Crotte) (Pini et al., 2012).

\section{Acknowledgments}

The authors are grateful to the Soprintendenza per i beni e le attività culturali of the Regione Autonoma Valle d'Aosta for the 
logistic and financial support. We thank two anonymous reviewers for improving the manuscript.

\section{References}

Aceti, A., 2006. The early Holocene climate optimum: evidence from high-altitude peat deposits in the Italian Alpes. In: INQUA-SEQS Congress, Quaternary Stratigraphy and Evolution of the Alpine Region in the European and Global Framework, September 11-15, 2006, pp. 48-49.

Angelucci, D.E., 1997. Nuovi dati sulla preistoria delle Dolomiti: la campagna di scavo 1994 nei siti mesolitici del Plan de Frea (Selva Val Gardena). Ladinia 20, 19-37.

Badino, F., Aceti, A., Maggi, V., Orombelli, G., Pini, R., Raiteri, L., Ravazzi, C., 2010. Fasi di massimo termico durante la prima metà dell'Olocene nella registrazione stratigrafica dei contesti glaciali e dei "travertini” nelle Alpi Centro-Occidentali. In: AIQUA Congress, Le correlazioni marino-continentali nel Quaternario, Bari, February 25-26, 2010, p. 66.

Bagolini, B., 1980. Il Trentino nella preistoria del mondo alpino. Temi, Trento.

Broglio, A., 1980. Culture ed ambienti della fine del Paleolitico e del Mesolitico nell'Italia nord-orientale. Preistoria Alpina 16, 7-29.

Broglio, A., Lanzinger, M., 1996. The human population of the southern slopes of the eastern Alps in the Wurm Late Glacial and early Postglacial. Il Quaternario, Italian Journal of Quaternary Sciences 9 (2), 499-508.

Brugiapaglia, E., 2007. Evoluzione altitudinale spazio-temporale degli alberi durante gli ultimi 12.000 anni in Valle d'Aosta (Italia). Il Quaternario, Italian Journal of Quaternary Sciences 20 (2), 195-212.

Crosta, G., 1996. Landslide, spreading, deep seated gravitational deformation: analysis, examples, problems and proposals. Geografia Fisica Dinamica Quaternaria 19, 297-313.

Dalmeri, G., Grimaldi, S., Lanzinger, M., 2001. Il Paleolitico e il Mesolitico. In: Lanzinger, M., Marzatico, F., Pedrotti, A. (Eds.), Storia del Trentino: la preistoria e protostoria. Il Mulino, Bologna. pp. 15-118.

Dalmeri, G., Lanzinger, M., 2001. The evolution of the environment and human population of the Adige basin at the end of the late Ice Age and in the early Holocene. Preistoria Alpina 34, 15-18.

Dal Piaz, G.V., Gianotti, F., Monopoli, B., Pennacchioni, G., Tartarotti, P., Schiavo, A. 2010. Note illustrative del Foglio 91 "Châtillon" della Carta Geologica d'Italia alla scala 1:50.000, con carta geologica alla scala 1:50.000. Servizio Geologico d'Italia, Roma.

Davis, B.A.S., Brewer, S., Stevenson, A.C., Guiot, J., 2003. The temperatures of Europe during the Holocene reconstructed from pollen data. Quaternary Science Review 22, 1701-1716.

De Giusti, F., Dal Piaz, G.V., Massironi, M., Schiavo, A., 2004. Carta geotettonica della Valle d'Aosta. Memorie Scienze Geologiche 55, 129-149.

Elter, G., 1987. Carte géologique de la Vallée d'Aoste, échelle 1:100.000. C.N.R. Centro Studi sui Problemi dell'Orogeno delle Alpi Occidentali, Edizioni S.E.L.C.A, Firenze, Italy.

Evin, J., Bintz, P., Monjuvent, G., 1994. Human Settlement and the last deglaciation in the French Alps. Radiocarbon 36 (3), 345-357.

Forno, M.G., Gianotti, F., Paganone, M., 2004. La grande frana storica della Becca France (Valle d'Aosta, Italia): un esempio significativo di accumulo di frana a cordoni paralleli. In: AIQUA Congress, La Geologia del Quaternario in Italia: temi emergenti e zone d'ombra, February 16-18 2004, Roma, pp. 114-115.
Forno, M.G., Gattiglio, M., Gianotti, F., Raiteri, L., Guerreschi, A., 2012a. Geological and archaeological evidence in the Becca France ridge (Valle d'Aosta, NW Italy). In: AIQUA Congress, The transition from natural to anthropogenic-dominated environmental change in Italy and the surrounding regions since the Neolithic, February 15-17 2012, Pisa.

Forno, M.G., Gattiglio, M., Gianotti, F., 2012b. Geological context of the Becca France historical landslide (Aosta Valley, NW Italy). Alpine and Mediterranean Quaternary 25 (2), 125-139.

Guerreschi, A., 1992. La fine del Pleistocene e gli inizi dell'Olocene. In: Guidi, A. Piperno, M. (Eds.), Italia preistorica. Editori Laterza, pp. 198-237.

Guerreschi, A., 1998. Il Mesolitico nell'Italia nord-orientale. In: Pessina, A. Muscio, G. (Eds.), Settemila anni fa, il primo pane. Ambiente e culture delle società neolitiche. Catalogo della Mostra, Udine, 1998-99, pp. 78-85.

Guerreschi, A., Raiteri, L., Di Maio, P., Ravazzi, C., Pini, R., Gabriele, P., Baster, I. 2010. A new high-altitude Mesolithic site on Mont Fallére (Aosta, northern Italy). First results on archaeology, environmental and landscape evolution. In: International Conference on Mesolithic in Europe MESO Congress. Santander.

Jalut, G., 2005. Le climat, la végétation et l'homme en Méditerranée à l'Holocène. In: Guilaine, J. (Ed.), Populations néolithiques et environnements. Errance, Paris, pp. $215-240$.

Kozlowski, S.K., 1973. The Mesolithic in Europe, Warszawa. In: International Archaeological Symposium on the Mesolithic in Europe. Warsaw University Press, Warsaw.

Mezzena, F., Perrini, L., 1999. Prima segnalazione di presenze Mesolitiche in Valle d'Aosta. L'industria litica in quarzo del Mont Fallère. Rassegna di Archeologia 16 85-95. Firenze.

Mezzena, F., Perrini, L., 2002. Mont Fallère. Des trouvailles mésolithiques au Va d'Aoste. In: Catalogue de l'exposition, Premiers hommes dans les Alpes, de 500000 à 5000 avant Jésus-Christ. Sion. Editions Payot, Lausanne, Suisse pp. 187-188.

Mortara, G., Sorzana, P.F., 1987. Fenomeni di deformazione gravitativa profond nell'arco alpino occidentale italiano. Considerazioni lito-strutturali e morfologiche. Bollettino Società Geologica Italiana 106, 303-314.

Pini, R., Aceti, A., Badino, F., Maggi, V., Orombelli, G., Raiteri, L., Ravazzi, C., 2011. High-altitude environments and glaciers fluctuations in the western sector of the Aosta Valley during the Holocene. In: AIQUA Congress, Il Quaternario Italiano: conoscenze e prospettive, February 24-25 2011, Roma. Il Quaternario, Italian Journal of Quaternary Sciences vol. 24, pp. 117-119.

Pini, R., Aceti, A., Maggi, V., Orombelli, G., Raiteri, L., Ravazzi, C., 2012. Holocene forest history and timberline fluctuations in the Western and Central Alps: the role of climatic factors and men. In: AIQUA Congress, The Transition From Natural to Anthropogenic-dominated Environmental Change in Italy and the Surrounding Regions Since the Neolithic, February 15-17 2012, Pisa.

Raiteri, L., Baster, I., Gabriele, P., 2008. Studio geologico-geomorfologico dell'area circostante il sito Mesolitico del M.te Fallère (Saint-Pierre). BSBAC, 5/2008, Quart (AO) 2010, p. 29.

Raiteri, L., 2009. La ricerca sul popolamento della Valle d'Aosta nell'Olocene antico: il sito Mesolitico di alta quota del Fallère. Tesi di Laurea Specialistica in Scienze Preistoriche. Università degli Studi di Ferrara.

Tinner, W., Theurillat, J.P., 2003. Uppermost limit, extent, and fluctuations of the timberline and treeline ecocline in the Swiss Central Alps during the past 11.500 years. Arctic and Alpine Research 35 (2), 158-169.

Zischinsky, U., 1969. Uber Sackungen. Rock Mechanics 1 (1), 30-52. 